\section{INCIDENCES OF BITUMEN CONTAMINATION OF WATER SOURCES IN SOME COMMUNITIES OF ONDO STATE, NIGERIA}

Eganoosi Esme Atojunere

Department of Systems Engineering, University of Lagos, Nigeria
Article history

Received

11 December 2020

Received in revised form

4 February 2021

Accepted

10 February 2021

Published online

31 March 2021

*Corresponding author

eatojunere@unilag.edu.ng

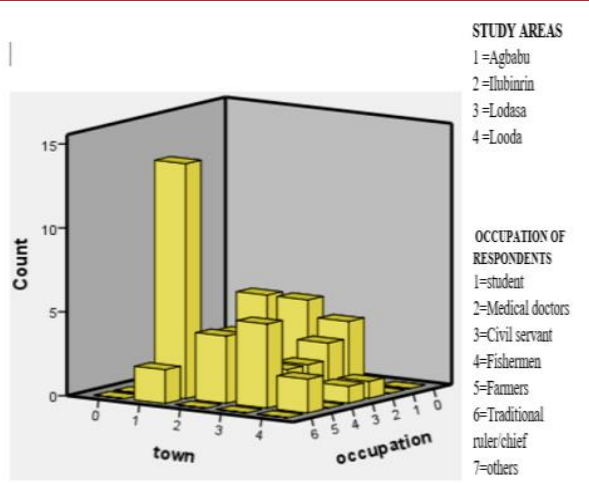

\begin{abstract}
Bitumen was discovered in some communities: Agbabu, llubinrin, Lodasa and Boridele in Ondo State, Nigeria around 1900 but was found inadequate for commercial exploitation. This report is on the levels of presence of bitumen in the areas and its effects on the available water sources and to make recommendations. Samples of water taken from 3 selected streams and 2 wells per location were subjected to physico-chemical analyses in line with America Public Health Association (APHA). Questionnaire were administered to sixty (60) people from bitumen-affected areas which covered sources of water, water pre-treatment measures, availability of water treatment facilities and effects of bitumen deposits on water bodies. Results obtained shown that most water users sourced water from groundwater recorded $73.33 \%$ followed by $16.67 \%$ for surface water and $9 \%$ for rain water harvesting. There might be population using a combination of the two or more sources of water. About $90 \%$ of the respondents knew that direct use of such water was harmful for drinking, washing, bathing and cooking. Water quality impairment such as colour and high level of salt are common in the water. This practice could have health implication on them if continued unabated. Pollution index for toxic metals ( $\mathrm{Pb}, \mathrm{As}$ and $\mathrm{Hg}$ ) and Total Petroleum Hydrocarbons(TPH) values determined were relatively high suggesting pollutant are related to the bitumen deposits in the region. For example llubinrin well $(0.5 \mathrm{mg} / \mathrm{L})$, and Lodasa well $(0.3 \mathrm{mg} / \mathrm{L})$ while others were at non detection level. For TPH, there were variations in the tested water samples, Lodasa well recorded the highest value of $1480 \mathrm{mg} / \mathrm{L}$, Agbabu stream 900, Ilubinrin stream and well $240 \mathrm{mg} / \mathrm{L}$ and $120 \mathrm{mg} / \mathrm{L}$, respectively, Agbabu well $110 \mathrm{mg} / \mathrm{L}$, and the least at Lodasa stream $80 \mathrm{mg} / \mathrm{L}$. This could be attributed to seasonal rain that control streamflow of water bodies in the bitumen-rich area. The study indicated that bitumen, being a complex mixture of hydrocarbons and associated metals was responsible to the pollution level in the water bodies reported
\end{abstract}

Keywords: Bitumen-deposits, water-pollution, water quality, treatment-facilities

(c) 2021 Penerbit UTM Press. All rights reserved

\subsection{INTRODUCTION}

Bitumen was discovered in Nigeria around 1900 [1]. Bitumen occurs in varying quantities in some parts of the world: Canada, Venezuela and Trinidad and Tobago. It is a generic term for the class of dark, viscous, heavy hydrocarbons found in petroleum, that occurs either naturally or formed as residues during fractional distillation of petroleum and coal. Bitumen has for long been used for adhesives in road construction, brick making and sealing of broken water gourds. It is also used as wood preservatives. The material was also used in waterproofing dug-out canoes and in embalming techniques as for Egyptian mummies. Natural bitumen is the thickest form of petroleum. It is made up of $83 \%$ carbon, $10 \%$ hydrogen and lesser amounts of oxygen, nitrogen, sulfur, and other elements. It is a natural polymer of low molecular weight with a remarkable ability to change with temperature variations. At lower temperatures, it is rigid and brittle, at room 
temperature it is flexible, at higher temperatures, it is much less viscous. Bitumen deposits in Nigeria lie on the onshore of Eastern Dahomey (Benin) basin and spans four States: Edo, Lagos, Ondo and Ogun states. In Ondo State, the bitumen areas span six out of the eighteen Local Government Areas namely: Idanre, Odigbo, Irele, Okitipupa, Ilaje and Ese-Odo. Seepages from bitumen deposits in these areas have been observed in water bodies for decades causing impairment to water quality. Water contamination by bitumen has generated little public outcry among water users compared to pollution by crude oil in oceans and high seas probably because it viewed as a localized problem. Several rivers flow across the bitumen belt in Ondo State from north to south including in Oluwa, Siluko, Oni, Benin and Italita have been negatively impacted by the flow of bitumen. The River Oluwa (Figure 1) and its tributaries were major sources of water for indigenes living in the bituminous belt of Ondo State, Nigeria. Bitumen tar were conveyed from one stream to another by water after detachment from the parent bitumen due to change in temperatures and viscosities [2]. Bitumen-polluted water contained pollutants that are of public health concerns such as heavy metals and petroleum hydrocarbons $[3,4,5]$. Bitumen pollution occurs when petroleum from ground reservoir seeps to the ground surface through cracks or faults on ground as a result of changes in temperature and or bacterial degradation [6]. This report is on the levels of presence of bitumen in the areas and its effects on the available water sources and to make recommendations. This physico-chemical change leads to evaporation of volatile hydrocarbon fractions leaving molasses called bitumen, however, this remain is very toxic to any receiving stream in the area. Bitumen deposits found in these communities has negative effects on water and soil as farmlands in these communities were covered with bitumen deposits, adversely affecting, making farming and livelihood in the areas.

\subsection{METHODOLOGY}

Some bitumen-rich communities of Ondo State: Agbabu, Ilubirin, Boridele and Lodasa communities were visited. The communities were found in Odigbo Local Government area which have one of the largest deposits of bitumen deposits in the State found at coordinates $6^{\circ} 47^{\prime}$ North and $4^{\circ} 52^{\prime}$ East as shown in Figure 1. The areas experienced two seasons of wet (April to September) and dry seasons (October to March). The neighboring communities have no confirmed bitumen deposits. Temperature changes resulted into bitumen flow due to lower viscosity. Tar balls from the detached deposits were conveyed round these communities by water. Heap of bitumen was found accumulated at river banks in this region (Figure 2). Close examination of the stream revealed that bitumen has impacted negatively of physical quality of water in the area (Figure 3). Agbabu, being the most populated. The main occupations of the people in of the area are farming (fish farming included), log and latex production.

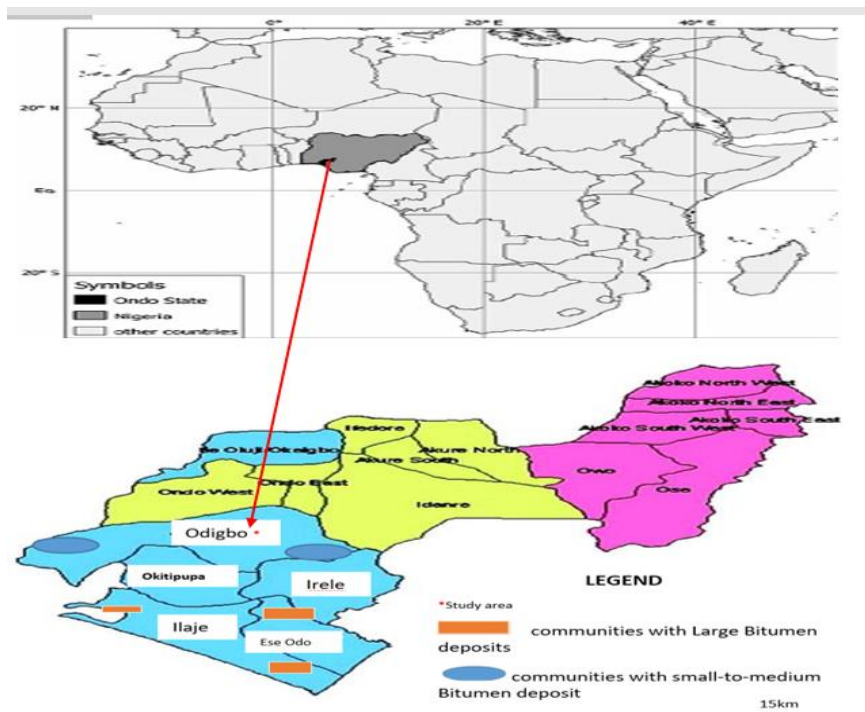

Figure 1 : Sample area Odigbo, Ondo State Nigeria in African map. Source: https://www.google.com/search?q=Nigeria+in+african+map

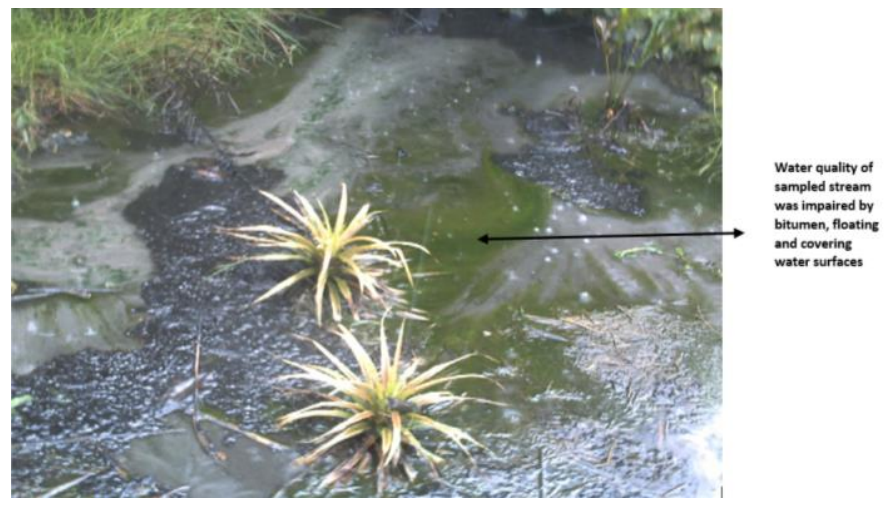

Figure 2 Algae boom formed on a bitumen-laden surface water in Ilubirin, Ondo State

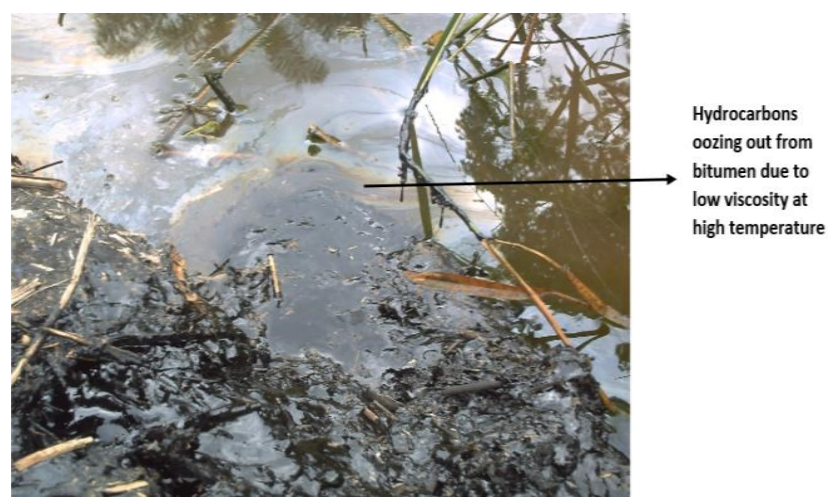

Figure 3 Heap of accumulated bitumen found along the river bank at Agbabu, Ondo State, Nigeria 


\subsection{Water Samples Collection}

500-ml glass containers were used to collect grab samples of water from bitumen-laden stream and wells at Agbabu, llubirin and Lodasa communities and sample were taken in duplicates at depths $10-20 \mathrm{~cm}$. These wells are shallow less than 50 feet deep. Some of the wells where samples were taken were not covered and few that have covered were found stained with bitumen (Figures 4 to Figure 5). The water sampling method followed procedure outlined in [7]. The points of collection for surface water (Figure 6) were selected close to observatory bitumen wells dug in the areas which periodically oozed out bitumen during temperature rise. Six $500-\mathrm{ml}$ glass containers were used for water collection were thoroughly washed, rinsed with hot water and dried at room temperature before usage. The samples (Figure 7) were transported directly to the laboratory at the Department of Chemistry, University of Lagos, Nigeria for physico-chemical analyses. Different containers were used to collect water sample for metal and hydrocarbons analyses, to avoid contamination $0.2 \mathrm{ml}$ of Hydrogentrioxonitrate $\mathrm{V}\left(\mathrm{HNO}_{3}\right)$ acid (Nitric acid) was added to keep available metals in solution during transportation before analyses.

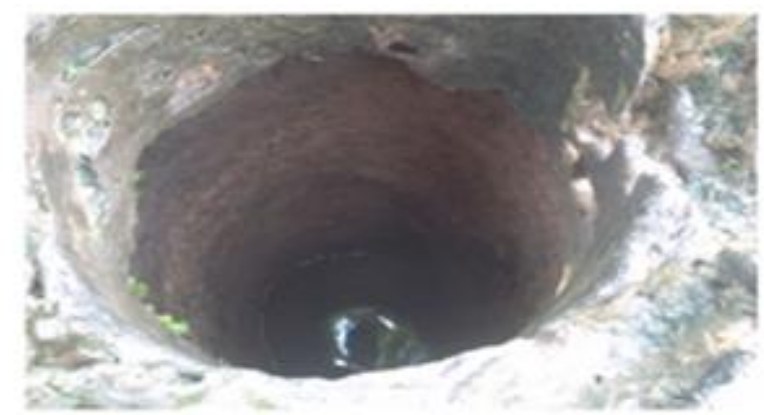

Figure 4: Sampled Shallow well < 50ft without cover

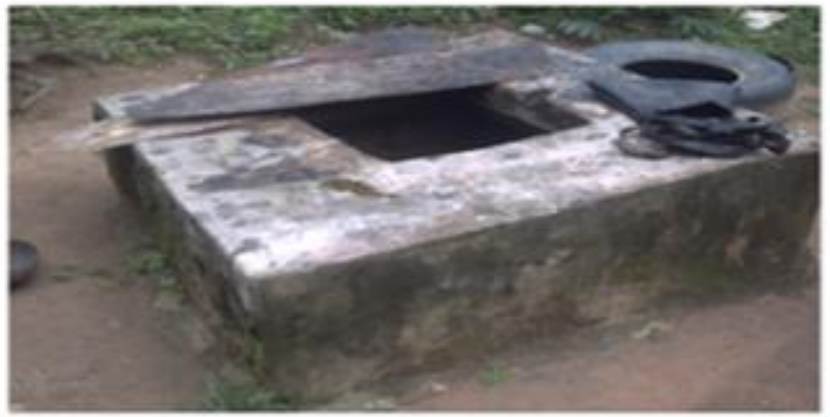

Figure 5:Sampled concreted shallow well with covered stained with bitumen

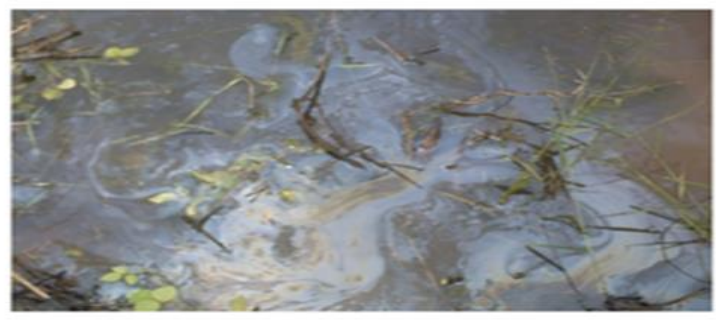

Figure 6: Sampled bitumen-polluted floving stream

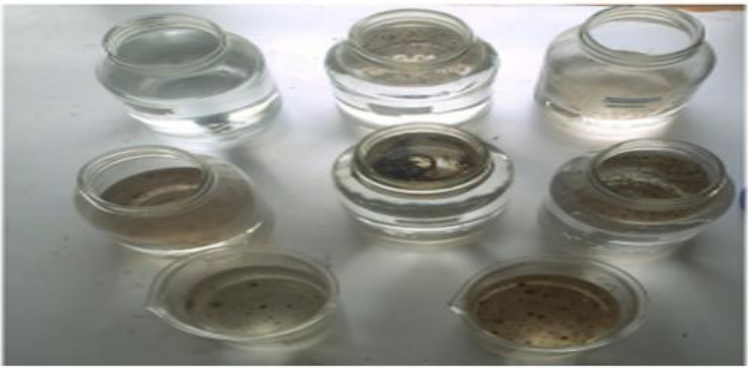

Figure 7: Sampled bitumen-polluted water for analyses

The study area experiences two rainy seasons with average rainfall ranging from $900 \mathrm{~mm}$ to $1,200 \mathrm{~mm}$ per annum and average temperature range between $8.40 \mathrm{C}$ and $270 \mathrm{C}$ (Kemboi et al., 2018). Rocks in the study area are volcanic. Soils are primarily red to strong-brown friable clays with laterite horizon and gleysols that do not drain easily (Kiptum and Ndambuki, 2012).

\subsection{Questionnaire Survey on Bitumen -polluted Stream}

60 copies of questionnaire were administered to the people living in these areas. They were carefully selected in order to obtain representative data. Respondents include farmers who dominated the area and do farm on bitumen-polluted soil, civil servants mainly school teachers who seems to have knowledge about the deposits, village heads/chiefs (most of them are former worker to the Nigeria bitumen corporation responsible for digging bitumen observatory well). Agbabu had 30 respondents because of its size followed by llubinrin, Lodasa and Looda having 10 respondents each. It was designed to identify the people's water sources, available water pretreatment measures done by the villagers such as boiling, sedimentation before water use, water treatment facilities decontaminate bitumen-polluted water, their knowledge about the presence of bitumen were tested, and effects of bitumen on the people's live, occupation, crops and soil.

\subsection{Statistical Analyses}

Data obtained from respondents were statistically analyzed using both descriptive statistics and Statistical Package for the Social Science (SPSS) V27 software. Charts were plotted to show relative variations among experimented variables. 


\subsection{RESULTS AND DISCUSSION}

As shown in Table 1 and Figures 8 to Figure 11 the water source in the bitumen-rich areas are $73.33 \%$ for groundwater, $16.67 \%$ for surface water and $9 \%$ for others. The residents in the area are of the opinion that groundwater is less polluted. However, published works have found that this is incorrect [9].

Table 1 Results of physico-chemical tests on water samples from bitumen affected water bodies

\begin{tabular}{|c|c|c|c|c|c|c|c|c|}
\hline Sources & $\mathrm{TPH} \mathrm{mg} / \mathrm{L}$ & Arsenic mg/L & $\begin{array}{l}\text { Lead } \\
\mathrm{mg} / \mathrm{L}\end{array}$ & Mercury mg/L & $\begin{array}{c}\text { Nitrate } \\
\mathrm{mg} / \mathrm{L}\end{array}$ & $\begin{array}{c}\text { Organic } \\
\text { Nitrogen }\end{array}$ & $\begin{array}{c}\text { Temperature } \\
{ }^{\circ} \mathrm{C} \\
\end{array}$ & $\mathrm{mg} / \mathrm{L}$ \\
\hline Agbabu stream & $850-950$ & ND & ND & ND & $3.62-3.90$ & $0.4-0.8$ & $25.7-31.7$ & $200-296$ \\
\hline Ilubinrin stream & $200-280$ & ND & ND & ND & $0.70-0.86$ & $\begin{array}{l}0.10- \\
0.26\end{array}$ & $25.3-31.3$ & $250-310$ \\
\hline Lodasa stream & $60-100$ & ND & ND & ND & $2.40-2.64$ & ND & 25.1-31.1 & $250-350$ \\
\hline Agbabu well & $100-120$ & ND & ND & ND & $2.60-2.72$ & ND & 25.1-31.1 & $160-200$ \\
\hline Ilubinrin well & $100-140$ & ND & $0.4-0.6$ & ND & $1.74-1.92$ & ND & 25.1-30.1 & $300-372$ \\
\hline Lodasa well & $1440-1520$ & ND & $0.2-0.4$ & ND & $1.26-150$ & ND & 25.1-31.6 & $370-394$ \\
\hline
\end{tabular}

$\mathrm{ND}=$ None Detected, $\mathrm{TPH}=$ Total Petroleum Hydrocarbon

Table 2 Results obtained from the administered questionnaire in some of the bitumen-affected communities of Ondo State, Nigeria

\begin{tabular}{|c|c|}
\hline Items from questionnaire & Percentage (\%) per respondent/communities \\
\hline Respondents/community & 46.3\% from Agbabu; 26.7\% from Ilubinrin; $18.3 \%$ for Lodasa and 8.7\% from Looda \\
\hline $\begin{array}{l}\text { Respondents from each community that } \\
\text { are familiarity with bitumen history }\end{array}$ & $50 \%$ in Agbabu;31.7\% in Ilubinrin;16.7\% in Lodasa; and 1.6\% in Looda \\
\hline Major water sources & $\begin{array}{c}\text { 75\% use Groundwater(GW);18.8\% use Surface Water(SW),9\% rain and others } \\
1.67 \%\end{array}$ \\
\hline $\begin{array}{l}\text { Knowledge on effects on water, crops } \\
\text { and soil }\end{array}$ & $\begin{array}{l}75 \% \text { for respondents who were aware of any effect due to bitumen deposits on } \\
\text { water, soil and plant; } 18.3 \% \text { for respondents that are aware and } 6.7 \% \text { for not sure }\end{array}$ \\
\hline $\begin{array}{l}\text { Pre-treatments measures taken before } \\
\text { water usage }\end{array}$ & $\begin{array}{c}\text { 90\% for no pre-treatment measure taken before abstracted water from stream } \\
\text { and well were use; } 8.3 \% \text { for respondent that claimed to do some pre-treatments } \\
\text { such as boiling, sedimentation and chlorination before water usage and } 1.67 \% \text { for } \\
\text { others }\end{array}$ \\
\hline Availability of treatment facilities & $98.3 \%$ for no available treatment facility and $1.7 \%$ for not sure \\
\hline $\begin{array}{l}\text { Effects on human being, colouration of } \\
\text { items washed }\end{array}$ & $\begin{array}{l}\text { 83.3\% for respondents that claimed they were negative effect; } 11 \% \text { for no effect } \\
\text { respondent and } 5.7 \% \text { for not sure }\end{array}$ \\
\hline Experiencing oily skin with bathing & $\begin{array}{l}87.6 \% \text { for people that experienced oily skin and } 12.4 \% \text { for not experiencing oily } \\
\text { skin }\end{array}$ \\
\hline $\begin{array}{l}\text { Knowledge of any ailment caused by } \\
\text { bitumen ingestion }\end{array}$ & $\begin{array}{l}80 \% \text { for people that are non- aware; } 18.3 \% \text { for aware and } 1.7 \% \text { for people that are } \\
\text { not sure }\end{array}$ \\
\hline Identifying the colour of bitumen & $83.3 \%$ respondents identified bitumen to be black and $16.7 \%$ not sure \\
\hline Uses of bitumen & $\begin{array}{l}\text { Adhesive } 63.33 \% \text {, road paving } 15 \% \text {,for preservatives } 10 \%, \text { for both adhesive \& } \\
\text { sealant } 10 \% \text { and others } 1.67 \%,\end{array}$ \\
\hline Major occupations of respondents & $\begin{array}{l}41 \% \text { of the respondents were farmer: } 23.3 \% \text { were fishermen; } 28.7 \% \text { for civil } \\
\text { servants;5.0\% for traditional rulers and } 2 \% \text { for medical personnel }\end{array}$ \\
\hline
\end{tabular}

Their usual sources of water are groundwater/dug- well, with or without protective concrete ring less than $10 \%$ of the respondents apply chlorine to their groundwater wells within six months.

There is long contact time of interaction between the bitumen deposits (mostly subsurface) and with water bodies from the aquifer thereby causing water pollution $[10,11]$. This was noticeable in some physico-chemical indicators like taste, odour and salt level as many respondents reported. About $90 \%$ of the respondents indicated that they do not carry out any pre-treatment such as boiling, sedimentation or coagulation of the water before use and no water treatment facility was currently available in their communities. Some respondents reported itchiness of the body during water use for bathing. The need for large amount of soap used for washing and coloration of items washed especially clothes were well mentioned by most respondents. From Table 2 , all the samples tested showed concentrations of Total Petroleum Hydrocarbon (TPH $\mathrm{mg} / \mathrm{L}$ ). Lodasa wells recorded the highest $(1480 \mathrm{mg} / \mathrm{L})$, Agbabu stream $(900 \mathrm{mg} / \mathrm{L})$, Ilubinrin stream (240 
$\mathrm{mg} / \mathrm{L})$, llubinrin well (120 mg/L),Agbabu well (110 mg/L) and least at Lodasa stream $(80 \mathrm{mg} / \mathrm{L})$.The presence of TPH in the samples tested suggests pollution was partly due to petroleum compounds, and in this case the bitumen deposit found on ground surface and subsurface in the area. There are no anthropogenic sources such as mining, purification of metals, or waste water irrigation in the area under investigation $[12,13,14]$. Arsenic and Mercury were not detected in the samples tested but traces of lead were detected in llubinrin well $(0.5 \mathrm{mg} / \mathrm{L})$ and Lodasa well $(0.3 \mathrm{mg} / \mathrm{L})$. This is of public health concern as over $60 \%$ of respondents indicated that, their sources of water for domestic and other uses is groundwater. Groundwater pollution as a result of these mobile pollutants (lead, cadmium and chromium etc.) are well reported in literature. These toxic metals are associated impurities to bitumen [15]. Organic pollution was recorded in streams at Agbabu stream $(0.59 \mathrm{mg} / \mathrm{L})$ and Ilubirin stream $(0.18 \mathrm{mg} / \mathrm{L})$. TPH values and heavy metal $\mathrm{Pb}$ in tested sample were found above acceptable limit for drinking water by World Health Organization (WHO) and Federal Environmental Protection Agency (FEPA), while temperatures and others were within the recommended standard.

The presence of nitrogen may be due to sources such as animal wastes, use of agricultural chemicals (pesticides and herbicides) and waste water discharge, agriculture being the dominant business in the bitumen-rich areas as the respondents to the questionnaire reported. Nitrate concentration may suggest that organic nitrogen pollution has sufficiently occurred upstream in surface water and that the organics have long residence time to completely oxidize to nitrate. Nitrate may get into the aquifer through leaching. Nitrates move freely with groundwater flow. Nitrate poisoning in infants, can cause serious problems by competing with available oxygen which may lead to suffocation [16]. There is need for further research on the source of nitrate. The chemical oxygen demand values in all the tested water samples suggest organic pollution.

The uses of bitumen were as sealants for dugout canoe, broken water gourds and as mortars for road constructions. All the respondents identified the colour of bitumen to be black. The major occupations of respondents are agriculture and fishery.Lead $\mathrm{pb}$ associated with bitumen have no biological function [17]. It is harmful to human body due to their persistent nature and non-biodegradability.

Seep-out bitumen on soil surface releases these toxic metals to the environment. About $95 \%$ of the respondents are not aware of the danger attached to ingestion/inhalation of and skin contact with bitumen.

Over $90 \%$ of the respondents reported experiencing itchiness of the body during water use for bathing, large amount of soap is required for washing and colouration of clothes and some items washed. Bitumen imparts taste, colour and toxic chemicals to the water due to their long contact time. Filtration/boiling water is ineffective to reduce bitumen that is dissolved in water and other associated chemicals, less than $10 \%$ of the respondents resort to boiling/filtration. The temperature of water samples was within acceptable limit of $27-30^{\circ} \mathrm{C}$. Adverse effects of bitumen as colour, taste and odour of water, were known to the most respondents.

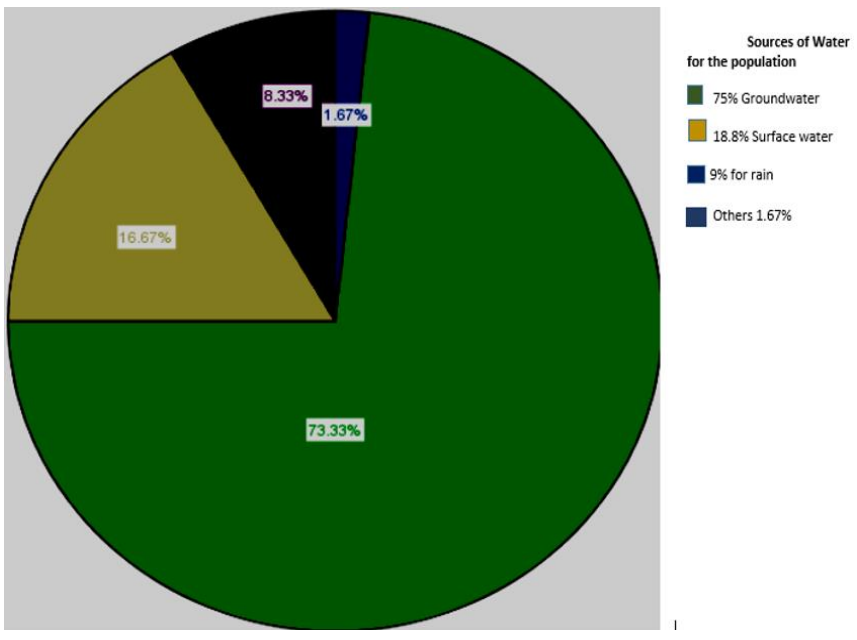

Figure 8 Sources of water to the resident of the bitumen-rich communities

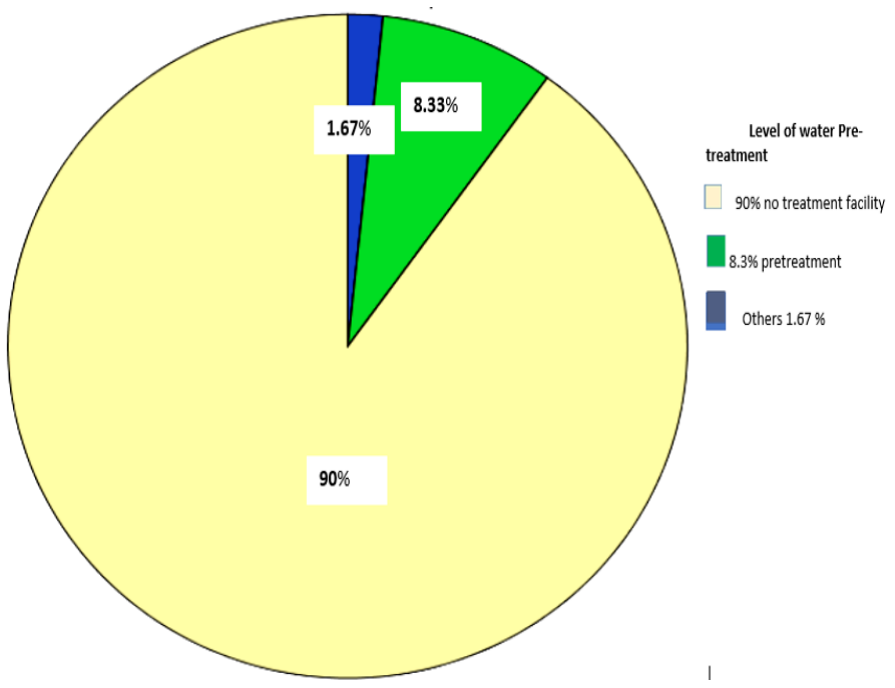

Figure 9 Level of water pre-treatment employed by residents of the bitumen-rich areas

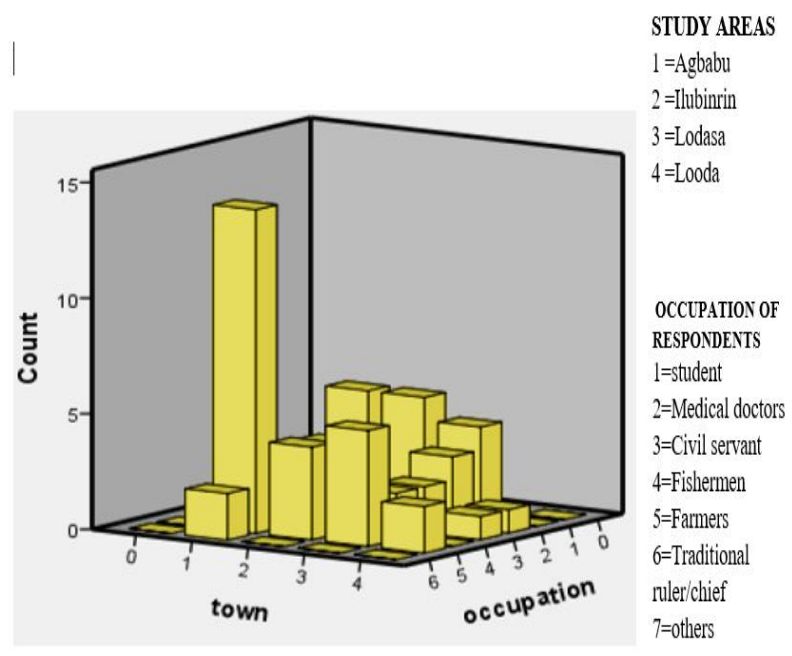

Figure 10 Occupations of respondents in the bitumen-rich areas 


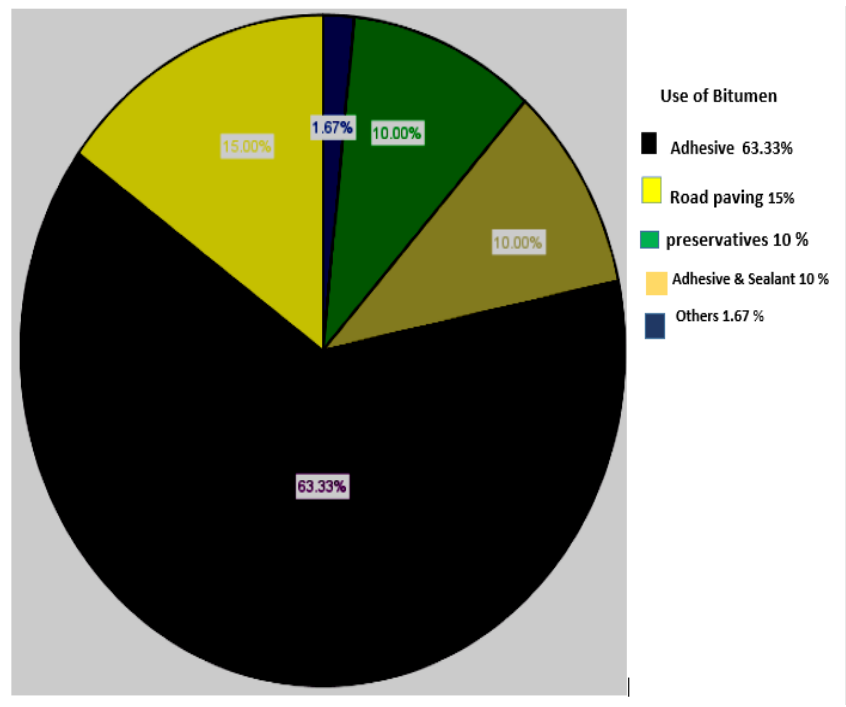

Figure 11: Bitumen usage in the bitumen-rich area

\subsection{CONCLUSION}

Analytical data obtained revealed varying level of water pollution caused by lead. The presence of lead metal could be attributed to bitumen deposit found in the region. Bitumen is used locally as sealant of broken water gourds for storing drinkable water. This may be one of the sources lead metal dissolved from bitumen pollute the waterbodies. There is presently no water treatment facility in the areas so direct intake of such water from streams could pose serious health problems. Water pre-treatment measures such as boiling and filtration done by some population is not a safe practice as recalcitrant pollutants and dissolved hydrocarbons can pass through the filter as filtrate. Lead pb is toxic, bioaccumulative, persistence could cause imbalance into waterbodies ecological systems. The heavy metal concentration was above the regulatory limits of World Health Organization Federal Environmental Pollution Agency, Nigeria suggesting that the water bodies in bitumen affected area as being polluted also influenced high concentrations of these metals. Villagers making use of the water body may indeed be exposed to some health risks.

\section{References}

[1] Adegoke, O.S. 2000. Historical perspective of bitumen/tar sand development in Southwestern Nigeria. Proc. of the $1^{\text {st }}$ International Summit on Bitumen in Nigeria, 131-140.

[2] Ondo State Government (OSG). 2004. Development of bitumen deposits, Ondo, Nigeria, Ministry of Environment and Mineral Resources, Ondo State, Nigeria

[3] Fagbote, E.O., Olanipekun, E.O. \& Uyi, H.S. 2014. Water quality index of the ground water of bitumen deposit impacted farm settlements using entropy weighted method. International Journal of
Environmental Science and Engineering. 11:127-138 https://doi.org/10.1007/s13762-012-0149-0

[4] Adebiyi, F.M, A.A. 2007. Omole Chemical and elemental characterization of components of Nigerian bitumen sands. Energy Sources. 29 (8): 669-676

[5] Kuforiji, T.S T.A. 2013. Ayandiran: Study of heavy metals pollution and physic-chemical assessment of water quality of River Owo, Agbara, Nigeria. International Journal of Water Resources and Environmental Engineering. 5 (7): 434-441

[6] Meyer, R. F., Attanasi, E. D. and Freeman, P.A. 2007. Heavy oil and natural bitumen resources in geological basins of the world; open-file report 2007-1084. United States., Geological Survey: Reston, VA.

[7] Bartram, J.,and Balance, R. 1996. Water quality monitoring - a practical guide to the design and implementation of fresh water quality and monitoring study UNEP/WHO, Chapman and Hall. London.,UNEP/WHO

[8] American Public Health Association APHA 2012. Standard Methods for the Examination of Water and WasteWater (21th edition), American Public Health Association, Washington DC

[9] Ajayi, M.O. 2013. Perspectives on socio-economics and Psychological effects of bitumen exploration on Host communities: A case study of Agbabu, Ondo State, Nigeria, Int. Journal of Science and Research (IJSR). 4(9):108-115, www.ijsr.net

[10] Atojunere,E.E.,K.Ogedengbe and S.O. Afolayan. 2010. Effects of Bitumen Deposits and Seepage on Soil-water Physico-chemical and Hydrological Properties in Agbabu, Southwestern, Nigeria, Global Journal of Engineering and Technology, Institute of Science and Technology, Calcutta, India. 3 (2): 257-261.

[11] Atojunere, E.E and K.Ogedengbe. 2019. Evaluating Water Quality Indicators of Some Water Sources in the Bitumen-Rich Areas of Ondo State, Nigeria, International Journal of Environmental Pollution and Remediation (IJPER). 7(1): 9-22. Avestia Publishing, Ontario, Canada https://ijepr.avestia.com/2019/002.html

[12] Atojunere, E.E.,K.Ogedengbe and E .B. Lucas. 2018. The Development of Filtration and Bioremediation Technique for Decontaminating Bitumen-Polluted Water. Proceedings of the $2^{\text {nd }}$ International Conference of Recent Trends in Environmental Science and Engineering (RTESE'18), Academy of Science, Engineering and Technology(ASET), Niagara Falls, Canada,.DOI:10.11159/rtese18.111 https://avestia.com/RTESE2018_Proceedings/files/paper/RTESE_111. pdf

[13] Atojunere E.E. 2017. Development of filtration and bioremediation technique for the decontamination of bitumen-polluted water, PhD. Thesis, Department of Agricultural and Environmental Engineering, University of Ibadan.

[14] Atojunere, E.E and K. Ogedengbe. 2019. Application of Bioremediation Technique as A Potent Input for the Decontamination of Bitumen-Polluted Water. Slovak Journal of Civil Engineering (SJCE), University of Tech., Bratislava. 27(4): 24$31 \mathrm{https} / / /$ content.sciendo.com/view/journals/sjce/27/4/articlep24.xml

[15] Timoney, K.P. and Lee P. 2011. Polycyclic aromatic hydrocarbons increase in Athabasca river delta sediment-temporal trend and environmental correlates Journal of Environmental Science and Technology. 45(10): $4278-4284$.

[16] Howard S.P. Rowe D.R., and Tchobanoglous G. 1985. Environmental Engineering. McGraw- Hill, New York. 7(8): 69-70.

[17] Nriagu, J.O., Blackson M.I. and Ocram K. 1996. Childhood Lead Poisoning in Africa, a Growing Public Health Problem. Journal of Science Total Environment. 181(2): 93-101. 